\title{
AGRICULTURAL MODELS IN EU FADN REGIONS AND CHANGES IN FARM PRODUCTIVITY AND INCOMES
}

\author{
Łukasz Kryszak $^{\bowtie}$ \\ Poznań University of Economics and Business, Poland
}

\begin{abstract}
The purpose of this paper is to present and compare the level of and changes in (total and partial) productivity and basic income categories in FADN regions. The regions were grouped into 4 clusters where relatively similar types of agriculture predominate. Changes in total factor productivity (TFP) were evaluated using the Malmquist index and Tokarski's method. The research showed that regions with extremely intensive agriculture achieved a high level of productivity and income. However, while there is little potential for productivity growth (especially through improved technical efficiency) in these areas, local farms implement technological progress. Regions with 'industrial' agriculture generally demonstrate low levels of TFP, which is however accompanied by growth due to advances in both efficiency and technology. In regions where less developed or more traditional agriculture predominates, low to medium levels of incomes and of partial and total productivity were observed whereas the growth rates for labor and land productivity were relatively high. Also, the key economic category for the farming sector, i.e. income from labor inputs, was observed to grow at a relatively high pace. Note that an analysis of productivity and profitability in agricultural holdings based on only one measure or research method can lead to hasty conclusions.
\end{abstract}

Keywords: Malmquist index, productivity analysis, farm income, FADN regions

\section{INTRODUCTION}

Despite the gradual evolution of the Common Agricultural Policy, the issues of factor productivity and agricultural income remain at its heart, in particular in the context of the European Model of Agriculture (Cardwell, 2004). In accordance with the European Union's policy, agriculture should be economically competitive and should also contribute to improvements in the standard of living in rural areas without putting too much strain on the natural environment (Arzeni et al., 2001). One of the key determinants of the sector's competitiveness is productivity which may be defined as the attainable production level per unit of factor used (labor, land, capital) or total factor productivity. On the other hand, increasing the standard of living in rural areas requires raising the income of the local population, including agricultural incomes. Productivity and profitability are closely linked both in theory and practice. For an agricultural holding, the objective of income maximization may result from both a commitment to efficiency and market conditions, as well as from political assumptions and demands of social justice (Rembisz, 2013). However, in the context of rising input prices and the farmers' inability to influence purchase prices, productivity growth is an essential channel for achieving balance both across the agricultural sector and at farm level (Rembisz, 2010). Under the assumption that, taking Gloy et al. (2002) as an example, the primary objective of a farm is to maximize income per labor unit (e.g. per AWU, Annual Work Unit, or FWU, Family Work Unit), then an increase in labor productivity is essential. On the other hand, due to a consistent decline in agricultural prices (Czyżewski, 2007), an increase

$\bowtie$ Msc Łukasz Kryszak, Department of Macroeconomics and Agricultural Economics, Poznań University of Economics and Business, Al. Niepodległości 10 St., 61-875 Poznań, Poland, e-mail: lukasz.kryszak@ue.poznan.pl; https://orcid.org/0000-0001-8660-9236 
in agricultural surplus does not necessarily translate into adequate income growth.

The above assumptions are of a general nature and apply to all agricultural holdings. However, it is widely known that agriculture as a whole, as well as the conditions under which it operates, vary widely across the EU. This is influenced by economic factors, including e.g. economic policy options and macroeconomic stability, as well as by historical, cultural, social and, last but not least, natural and climatic issues. All of these aspects make it possible to identify different types and models of agriculture within the EU. An analysis at member state level (e.g. old vs. new member states) is not sufficient, considering the significant differences in agricultural development conditions across EU-15 countries (e.g. Mediterranean vs. Scandinavian countries). Moreover, there are also significant differences within individual countries, manifested in the agrarian structure (e.g. central Spain vs. northern and southern Spain, southern Germany vs. northern and eastern Germany). Therefore, the region could be the appropriate level of analysis of income and competitiveness issues (cf. Idczak, 2001, Kleinhanss, 2015).

The purpose of this paper is to present and compare the level of and changes in (total and partial) productivity and basic income categories in the clusters of EU FADN regions dominated by relatively similar types of agriculture. To meet this goal, data for 110 regions in the 2004-2015 research period was used. The next part of this paper presents the theoretical foundations for the proposed classification of FADN regions. Then, the data and methods used in the work are discussed. The results are presented together with the discussion. The paper ends with a summary containing the basic conclusions from the analyses conducted.

\section{THEORETICAL FRAMEWORK FOR DEFINING AGRICULTURAL TYPES IN FADN REGIONS}

The formation of the dominant type of agriculture in a given area is a long-term process related to both internal and external factors that are global or at least transnational. For example, after 1960, the agricultural production growth rate in Asia and Africa was much higher than in developed countries (Alston and Pardey, 2014). Land productivity was improving dynamically in developing countries, however, the disparity in agricultural labor productivity (particularly important from the point of view of farm family income) between developed and developing regions of the world increased. It was related to a more extensive and labor-intensive type of farming in regions such as Africa, Asia or South America. Agriculture in more developed regions of the world also underwent significant changes. Demographic processes, economic and technological development, together with the political and economic environment and, above all, changes in the prices of productive inputs led to a process referred to as structural changes (Goddard et al., 1993). Changes in prices of relative inputs (mainly a fall in the capital-to-labor price ratio) became a catalyst for changes in resource relations and thus led to changes in productivity. These dependencies are illustrated by the example of changes in agriculture in the US and Japan (Hayami and Ruttan, 1970). The substitution of labor with other productive inputs was triggered by wage increases in both countries. The US are characterized by a relatively abundant supply of land, which made this factor relatively cheap and thus its use increased (an increase in the ratio of agricultural land per employee). It was also a stimulus for the development of more extensive production practices. Japan, on the other hand, faced a very limited amount of land that could be used for agricultural production. Therefore, higher capital inputs (e.g. fertilization) were used; this was supposed to stimulate the productivity of land. On the other hand, as early as in 1960, Sraffa (1960) noted that these changes are not necessarily permanent. At a given profit rate, a single production technique may be the most cost-effective. However, when it is used on an increasing scale, it gradually becomes more expensive and is being replaced by another. As a result of increased interest, the latter technique also becomes more expensive and the previous one is likely to be reinstated (reswitching).

Changes in economic conditions of agriculture, together with the emphasis on the social and environmental aspects of agricultural activity, prompted research into the stages of development and types and models of agriculture in order to structure them. These terms are sometimes used interchangeably, although in fact they differ (cf. Kryszak, 2018). However, the basic principle of different classifications is to take into account (together with social and environmental aspects) the changing relationship between the supply and productivity of productive inputs. As mentioned earlier, those changes are caused by: changing relative prices (which in turn result 
Table 1. Productivity of productive inputs and resource relations in selected classifications of historical periods, types and models of agriculture

\begin{tabular}{|c|c|c|c|c|}
\hline $\begin{array}{l}\text { ERA/TYPE/PHASE } \\
\text { IN THE MODEL }\end{array}$ & $\mathrm{Y} / \mathrm{W}$ & $\mathrm{Y} / \mathrm{C}$ & $\mathrm{Y} / \mathrm{L}$ & $\mathrm{C} / \mathrm{W}$ \\
\hline
\end{tabular}

Development stages of agriculture according to Fotima and Krasowicz (from: Zegar, 2012)

\begin{tabular}{lccccc}
\hline Traditional & -- & + & -- & -- & -- \\
Industrial & ++ & - & ++ & ++ & ++ \\
Post-industrial & ++ & $-/+$ & ++ & + & + \\
\hline
\end{tabular}

Land management regimes (eras) according to Jepsen et al. (2015)

\begin{tabular}{lccccc}
\hline Peasantry & - & $-/+$ & - & -- & + \\
Innovation and rights & -- & $-/+$ & $-/+$ & $-/+$ & - \\
Intensification & $-/+$ & $-/+$ & + & + & $-/+$ \\
Industrialization & ++ & - & ++ & ++ & ++ \\
Collectivization & + & - & + & ++ & ++ \\
$\begin{array}{l}\text { De-intensification and } \\
\text { commercialization }\end{array}$ & + & - & + & ++ & ++ \\
$\begin{array}{l}\text { Environmental } \\
\text { awareness }\end{array}$ & ++ & $-/+$ & ++ & + & + \\
\end{tabular}

Agricultural types according to Zegar (2012)

\begin{tabular}{lccccc}
\hline Natural farming & -- & $+/-$ & -- & -- & - \\
Traditional & - & + & $-/+$ & $-/+$ & - \\
Industrial & ++ & - & ++ & ++ & ++ \\
Integrated & ++ & $+/-$ & ++ & ++ & + \\
Organic & + & $+/-$ & $-/+$ & - & - \\
Ecological & + & $+/-$ & $-/+$ & - & - \\
\hline
\end{tabular}

Herlemann and Stamer model (1963)

\begin{tabular}{lcccccc}
\hline Condensation phase & - & $+/-$ & - & - & - \\
Intensification phase & + & - & + & + & $-/+$ \\
Mechanization phase & + & - & ++ & ++ & $-/+$ \\
Concentration phase & ++ & $-/+$ & ++ & ++ & + \\
\hline
\end{tabular}

++ denotes very high values of a given indicator, + high, + /- medium, - low, - - very low, Y - agricultural output, C - capital, W - labor, L - land

Source: own elaboration from the fact that a given country or region is equipped with a given factor), the level of economic development as well as natural and climatic conditions. For example, in regions with more favorable natural conditions, capital and land productivity can be expected to be higher than in regions where conditions are not conducive to agricultural production. In simple terms, it can therefore be assumed that the average values of productivity indicators and resource relations are proxy values for determining the types (models) of agriculture in EU FADN regions. Table 1 presents the selected classifications of types and models of agriculture together with an attempt to determine theoretical values of productivity measures and resource relations in particular types and development phases of agriculture.

The following phenomenon can be deduced from Table 1: along with the transition from more traditional to industrial forms of farming, there is an increase in labor productivity, capital-to-labor ratio and land productivity while capital productivity is decreasing. Moving to greener forms of farming would enable reducing the productivity of land or (sometimes) labor while improving capital productivity (by reducing certain costs and/ or increasing production value through improvements in its nutritional and health qualities).

\section{DATA AND METHODS}

The level and growth ratios of partial and total productivity as well as the evolution of farm income were analyzed in farms representative of particular regions of FADN in $22 \mathrm{EU}$ member states divided into 4 clusters. They were determined based on standardized values of real partial productivity indicators: labor, land and capital. ${ }^{1}$

Total productivity can be calculated using a number of potential measures which can be divided into two main groups: the frontier approach and the nonfrontier approach. The frontier approach uses relative figures. Based on the observation sample, units which

\footnotetext{
${ }^{1}$ An attempt was also made to include the variables related to resource relations in the cluster analysis but they proved to be highly correlated to productivity. In addition, some regions (Cyprus, Malta, the City of Hamburg, the Balearic Islands, the Canary Islands and Denmark) were eliminated as outliers. Details of the following grouping procedure can be found in (Kryszak, 2018).
} 
demonstrate the greatest efficiency in transforming inputs into outputs are identified. The efficiency of other units is compared to the leading ones, referred to as the best practice frontiers. Both frontier and non-frontier measures are divided into parametric and non-parametric measures (Frija et al., 2015). The main difference is that measures of a parametric nature require the formulation of a production function so that the relevant parameters can be estimated.

In this paper, two methods of calculating TFP are used. Firstly, a parametric non-frontier method was used as per the formula proposed by Tokarski (1) (Dańska-Borsiak, 2011) (or the author's own modified version for the agricultural sector (2)). The TFP is calculated according to the following formulas:

$$
\mathrm{TFP}_{\mathrm{it}}=\frac{\left(\frac{\mathrm{Y}_{\mathrm{it}}}{\mathrm{W}_{\mathrm{it}}}\right)}{\left(\frac{\mathrm{C}_{\mathrm{it}}}{\mathrm{W}_{\mathrm{it}}}\right)^{\alpha}}(1) \text { or } \mathrm{TFP}_{\mathrm{it}}=\frac{\left(\frac{\mathrm{Y}_{\mathrm{it}}}{\mathrm{L}_{\mathrm{it}}}\right)}{\left(\frac{\mathrm{C}_{\mathrm{it}}}{\mathrm{W}_{\mathrm{it}}}\right)^{\alpha} \times\left(\frac{\mathrm{L}_{\mathrm{it}}}{\mathrm{W}_{\mathrm{it}}}\right)^{\beta}}(2),
$$

$\alpha$ and $\beta$ coefficients are calculated by estimating the following equation (e.g. using a fixed-effects panel regression model)

$$
\begin{gathered}
\ln \left(\frac{Y_{i t}}{W_{i t}}\right)=\sum_{i=1} d_{i}+g t+\alpha \ln \left(\frac{C_{i t}}{W_{i t}}\right) \\
\text { or } \\
\ln \left(\frac{Y_{i t}}{W_{i t}}\right)=\sum_{i=1} d_{i}+g t+\alpha \ln \left(\frac{C_{i t}}{W_{i t}}\right)+\beta \ln \left(\frac{L_{i t}}{W_{i t}}\right)
\end{gathered}
$$

where $t$ denotes the period to follow (to account for technical progress, as understood by Hicks) and $\mathrm{d}_{\mathrm{i}}$ is the individual effect in a single region.

In addition, a non-parametric frontier method was used, namely the Malmquist TFP index based on the DEA (data envelopment analysis) method. The Malmquist indices have two main advantages over other approaches. Firstly, they do not require the adoption of a specific form of the production function. Secondly, they can be used when no information is available on input and output prices.

The Malmquist TFP index identifies the role of the unit's technical efficiency, whereas the non-frontier approach assumes that the units are technically fully efficient. This measure is dynamic in nature, as it traces the changes in TFP from one period to another. The frontier approach also allows to decompose the TFP and identify its changes caused by exogenous technical progress (technological change) and improvements in the unit's production efficiency (technical efficiency change). In this study, a specification aimed at output maximization was selected, as it seems to be in line with the aspirations of most farms and is a rational choice from a microeconomic point of view. In an output-oriented approach, "differences in productivity are treated as differences in the level of maximum output for given input levels" (Ćwiąkała-Małys and Nowak, 2011).

The 'output' of the following formula is the total output of a farm. The inputs are: capital ${ }^{2}$ (intermediate consumption and depreciation), total labor input (in AWU) and total land input (in ha). The value of the indicator is calculated with the following formula (Fare et al. 1994):

$$
\begin{aligned}
& \mathrm{m}_{0}\left(\mathrm{y}_{\mathrm{t}+1}, \mathrm{x}_{\mathrm{t}}, \mathrm{y}_{\mathrm{t}}, \mathrm{x}_{\mathrm{t}}\right)= \\
& =\left[\frac{\mathrm{d}_{0}^{\mathrm{t}}\left(\mathrm{x}_{\mathrm{t}+1}, \mathrm{y}_{\mathrm{t}}, \mathrm{x}_{\mathrm{t}+1}\right)}{\mathrm{d}_{0}^{\mathrm{t}}\left(\mathrm{x}_{\mathrm{t}}, \mathrm{y}_{\mathrm{t}}\right)} \times \frac{\mathrm{d}_{0}^{\mathrm{t}+1}\left(\mathrm{x}_{\mathrm{t}+1}, \mathrm{y}_{\mathrm{t}}, \mathrm{x}_{\mathrm{t}+1}\right)}{\mathrm{d}_{0}^{\mathrm{t}+1}\left(\mathrm{x}_{\mathrm{t}}, \mathrm{y}_{\mathrm{t}}\right)}\right]^{1 / 2}
\end{aligned}
$$

where $\mathrm{x}$ and $\mathrm{y}$ denote vectors of effects and inputs, respectively, in period $\mathrm{t}$ and $\mathrm{t}+1$, whereas $d_{0}{ }^{t}$ and $d_{0}{ }^{t+1}$ denote the distance function.

At the $3^{\text {rd }}$ stage of research, referring to the relationship between productivity and income levels in agriculture, the level of and changes in basic categories of agricultural income (determinable based on FADN data) were analyzed. These were net value added/AWU, net income/AWU, Family Farm Income/FWU, net value added/hectare, return on equity (ROE) and profit from management which is calculated as net income less the cost of own productive inputs plus interest paid ${ }^{3}$. The costs of using the farmer's own land and labor were calculated based on the costs of rented land and hired labor, while the cost of equity was calculated as the capital of an agricultural holding (average farm capital) multiplied by the real interest rate (long-term interest rate less

${ }^{2}$ External costs were not taken into account when calculating the Malmquist TFP in order to avoid double-counting of certain inputs (e.g. hired work, rented land). Total resources of these factors (own resources and rented resources) were assumed to be labor and land inputs.

${ }^{3}$ After 2013, only the balance of interest paid and received is recorded in the FADN database. Therefore, this category is used in the present calculation. However, farmers are rather payers than receivers of interest, so it seems that the balance may serve as a proxy in this context. 
inflation). Income was deflated using the Harmonized Index of Consumer Prices (constant prices from 2004).

\section{RESULTS AND DISCUSSION}

The cluster analysis resulted in establishing 4 clusters of FADN regions with farms at similar partial productivity levels (cf. Fig. 1 and Kryszak, 2018). Table 1 presents the average levels and average growth rates (geometric averages) of partial productivity and resource relations in particular clusters of regions.

Cluster A covered only 7 regions, including Flanders, the Netherlands and five Italian regions, all characterized by highly intensive types of agricultural activity, as reflected in extremely high values of land and labor productivity. Farms are small in size but hold very large amounts of capital. At the same time, however, it is possible to achieve satisfactory productivity values also for the latter factor. On the other hand, in this cluster, real labor productivity increased at the slowest pace $(2.7 \%$ p.a.) while land productivity remained more or less stable. This indicates that the potential for output growth through input use growth is being gradually exhausted. It is therefore not surprising that in this cluster, the increase in the capital-to-labor ratio progressed at the relatively slowest rate $(1.3 \%$ p.a. $)$, while the amount of capital per unit area was decreasing (at an average rate of ca. $1.6 \%$ p.a.). Cluster B includes the northern and north-western European regions which rely on the industrial type of agriculture. This is evidenced by the highest values of labor productivity and significant values of the capital-to-labor ratio with a low value of capital productivity. Cluster B is dominated by large farms (both in economic and physical terms) whose income-generating strategy relies on economies of scale. Interestingly, changes in labor productivity (an average annual growth rate of $3.4 \%$ ) and in capital-to-labor ratio $(1.9 \%)$ yielded, only to farms in cluster $\mathrm{D}$, despite its high initial values of the analysed measures. The landto-labor ratio, on the other hand, increased at the slowest pace. It seems that the concentration processes in this cluster are so advanced that further increasing the average farm size is no longer a key strategy for increasing production and income. Cluster $\mathrm{C}$ comprises the Mediterranean regions (excluding northern Italy). Due to the specific production conditions, a labor-intensive type of production is carried out there, and therefore labor productivity is at one of the lowest levels. At the same

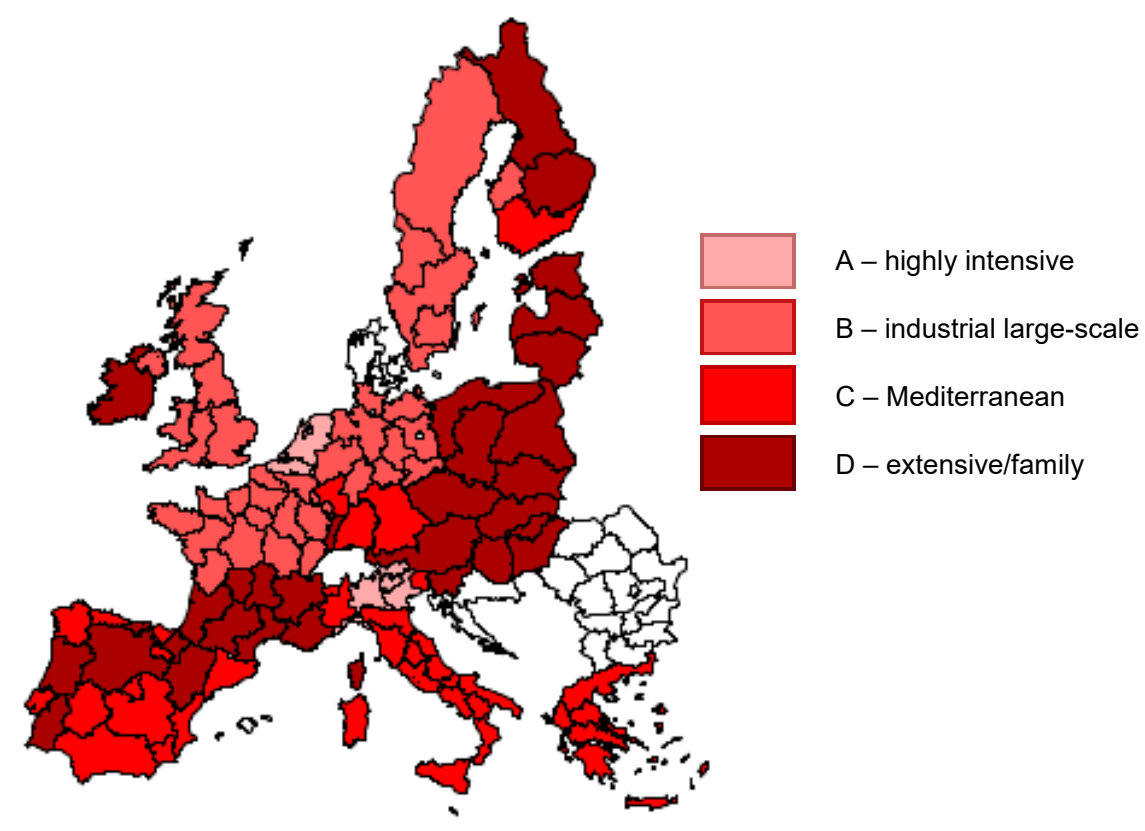

Fig. 1. Clusters of FADN regions with similar productivity of inputs Source: own elaboration based on FADN database 
Table 2. Mean values of and changes in productivity and resource relations in delimited clusters (2004-2015)

\begin{tabular}{lrrrrrrrr}
\hline \multirow{2}{*}{ Variable } & \multicolumn{3}{c}{ Mean (EUR thousand) } & \multicolumn{5}{c}{ Average growth rate } \\
\cline { 2 - 9 } & \multicolumn{1}{c}{$\mathrm{A}$} & \multicolumn{1}{c}{$\mathrm{B}$} & \multicolumn{1}{c}{$\mathrm{C}$} & $\mathrm{D}$ & $\mathrm{A}$ & $\mathrm{B}$ & $\mathrm{C}$ & $\mathrm{D}$ \\
\hline Labor productivity & 74.0 & 92.8 & 33.0 & 39.5 & 2.7 & 3.4 & 3.0 & 3.5 \\
Capital productivity & 1.9 & 1.1 & 2.0 & 1.3 & 1.5 & 1.4 & 1.3 & 1.1 \\
Land productivity & 8.0 & 1.8 & 2.5 & 1.4 & 0.0 & 2.2 & 0.4 & 1.5 \\
Capital/labor ratio & 45.7 & 80.8 & 16.9 & 32.2 & 1.3 & 1.9 & 1.7 & 2.3 \\
Land/labor ratio & 9.8 & 57.5 & 16.8 & 30.5 & 2.8 & 1.2 & 2.7 & 2.0 \\
Capital/land ratio & 4.1 & 1.4 & 1.2 & 1.1 & -1.6 & 0.8 & -0.9 & 0.4 \\
\hline
\end{tabular}

Source: own calculations based on the FADN database.

time, it is possible to achieve a relatively high value of production from capital expenditure, and the productivity of land is second only to that recorded in cluster A. Similarly as in cluster A, cluster C demonstrated more distinct concentration processes (the land-to-labor ratio increased at an average annual rate of $2.7 \%$ ). Land productivity and capital productivity improved, but rather slowly compared to other clusters. In the context of a generally low level of labor productivity, an improvement at a rate of 3\% p.a. should be assessed as moderate (and is lower than in clusters B and D). Cluster D covered southern France and Germany, northern Spain, Austria, Ireland and regions which joined the EU in 2004. The accession to the EU gave a strong momentum to many regions in cluster $\mathrm{D}$. As a consequence, in 2004-2015, the highest growth of labor productivity and relatively high growth of land productivity were recorded in this cluster. However, the average levels of these indicators remained rather low throughout the period. The capital-to-labor ratio also improved relatively fast. As for the concentration ratio, on the other hand, it increased at an average rate of $2 \%$ p.a. but was lower than in clusters A and C. To sum up, only in some cases the expected trend was observed, consisting in a particularly rapid improvement of the above indicators whose average level was relatively low compared to other clusters. Such tendencies are most visible in cluster D. However, cluster B is an interesting case because despite advanced industrialization processes, the growth of labor productivity and of the capital-to-labor ratio was still relatively high in the period considered.
Studies on European agriculture show that labor productivity differed across regions in earlier periods, too (e.g. 1950-2005). As a result of the inclusion of CAP mechanisms, and due to dynamic technical progress and population outflow to non-agricultural jobs, the increase in labor productivity in agriculture in developed countries was much faster than in the eastern part of the continent (Martín-Retortillo and Pinilla, 2015).

Total productivity (TFP) was analyzed using the parametric method proposed by Tokarski and the non-parametric Malmquist index. Apart from the technical differences indicated in the methodological part, it should be stated that Tokarski's method is useful to show the average productivity level while the Malmquist index shows the changes in productivity over time.

To estimate the TFP level according to Tokarski, it was first necessary to estimate the values of coefficients $\alpha$ and $\beta$ using equations (3) and (4). Then, the values of the coefficients were inserted into the TFP equations in the specifications (1) and (2) (see Table 3).

The highest average TFP level was observed in farms located in cluster A, i.e. the cluster with relatively high labor and capital productivity figures and extremely high land productivity values. The second highest average TFP level was observed in cluster C farms ("Mediterranean" farms) which achieved high levels of land productivity and low labor productivity ratios. In cluster B, characterized by low capital productivity and high labor productivity, the total factor productivity was $25 \%$ lower than in cluster A. The lowest TFP was recorded in cluster $\mathrm{D}(63 \%$ of the value for cluster $\mathrm{A})$. This indicates 
Table 3. Mean values of TFP in delimited clusters in 2004-2015

\begin{tabular}{|c|c|c|c|c|c|c|c|}
\hline \multicolumn{4}{|c|}{$\mathrm{TFP}_{\mathrm{it}}=\frac{\left(\frac{\mathrm{Y}_{\mathrm{it}}}{\mathrm{W}_{\mathrm{it}}}\right)}{\left(\mathrm{C}_{\mathrm{it}}\right)^{0.758}}$} & \multicolumn{4}{|c|}{$\mathrm{TFP}_{\mathrm{it}}=\frac{\left(\frac{\mathrm{Y}_{\mathrm{it}}}{\mathrm{L}_{\mathrm{it}}}\right)}{\left(\frac{\mathrm{C}_{\mathrm{it}}}{\mathrm{W}_{\mathrm{it}}}\right)^{0.753} \times\left(\frac{\mathrm{L}_{\mathrm{it}}}{\mathrm{W}_{\mathrm{it}}}\right)^{0.009}}$} \\
\hline \multicolumn{4}{|c|}{$\begin{array}{c}\text { Estimates: C/W: } 0.758 * * * \text {; period }(\mathrm{t}) 0.013 * * * \text {; } \\
\text { within } \mathrm{R}^{2} 0.70 ; \text { LSDV R } 0.98\end{array}$} & \multicolumn{4}{|c|}{$\begin{array}{c}\text { Estimates: C/W: } 0.758^{* * *} \text {; period (t) } 0.013^{* * *} \text {; } \\
\text { within } \mathrm{R}^{2} 0.70 ; \mathrm{LSDV} \mathrm{R}^{2} 0.98\end{array}$} \\
\hline \multicolumn{8}{|c|}{ Cluster } \\
\hline A & B & $\mathrm{C}$ & $\mathrm{D}$ & A & B & $\mathrm{C}$ & $\mathrm{D}$ \\
\hline 23.7 & 17.6 & 21.0 & 14.9 & 24.5 & 18.0 & 21.5 & 15.3 \\
\hline
\end{tabular}

Source: own calculations based on the FADN database

that agriculture in these regions suffers from technological backwardness resulting in inefficient resource use. The introduction of the second factor (land-to-labor ratio) to the denominator of the TFP formula does not significantly change the conclusions. In addition, this element proved to be statistically insignificant.

As regards regions with the highest and lowest TFP levels, the first quartile included some Benelux regions (Flanders, Netherlands), Italian and Spanish regions (both coastal and some central), as well as ChampagneArdenne and Peloponnese. Interestingly, in the case of Spain, both representatives of the northern part of the country where agriculture is more intensive (e.g. Galicia), and of the central part (e.g. Madrid), where a more extensive type of farming is practiced, are ranked in the first quartile. The last quartile included the new EU regions, as well as Portuguese regions, some Scandinavian regions (especially Finnish ones), individual French regions (Auvergne, Midi-Pyrénées), Austria and the Saarland.

An analysis of TFP changes in the light of Malmquist indices provides interesting conclusions (Table 4). In cluster A, with the highest average productivity level calculated using the Tokarski's method, the lowest productivity dynamics were observed. The growth rate for TFP was $1.5 \%$ p.a. This was mainly due to technological progress, suggesting that new technologies have been successfully tapped into. On the other hand, pure technical efficiency remained stable or even slightly decreased. Scale efficiency also slightly deteriorated. The highest growth of TFP was observed in cluster B where total productivity increased on average by $2.3 \%$. When it comes to partial productivity, it should be recalled that cluster B demonstrated a relatively high growth rate of land and labor productivity despite relatively high initial values (especially of the latter factor). Cluster B saw an improvement both in technological efficiency and in pure technical efficiency related to the use of resources. This shows that the development path followed by farms in cluster B regions consists in a more rational use of resources rather than in extending the resource pool, especially because despite high growth rates, the overall productivity level was relatively low in this cluster

Table 4. Mean values and decomposition of the Malmquist index in delimited clusters in 2004-2015

\begin{tabular}{lcccc}
\hline \multirow{2}{*}{ Decomposition } & \multicolumn{4}{c}{ Mean values } \\
\cline { 2 - 5 } & $\mathrm{A}$ & $\mathrm{B}$ & $\mathrm{C}$ & $\mathrm{D}$ \\
\hline MALMQUIST ind. & 1.015 & 1.023 & 1.019 & 1.018 \\
MIN & 0.984 & 1.004 & 0.986 & 0.997 \\
MAX & 1.032 & 1.063 & 1.044 & 1.061 \\
Pure tech. eff. change & 0.998 & 1.006 & 0.997 & 1.000 \\
Scale eff. change & 0.998 & 1.001 & 0.996 & 0.998 \\
Technological change & 1.018 & 1.016 & 1.026 & 1.021 \\
\hline
\end{tabular}

Source: own calculations based on the FADN database. 
(cf. Table 3). Moderate productivity growth was recorded in clusters $\mathrm{C}$ and $\mathrm{D}$ (1.9\% and $1.8 \%$, respectively), although high growth rates were recorded in some regions covered by these clusters. In both cases, the improvement was mainly due to technological progress. These results suggest that the basic way to improve productivity in European agriculture is to embark on the path of technological progress.

The regions with the highest growth in productivity included those in northern Europe (Finland, Sweden, Latvia, Estonia), some Italian and Spanish regions (mainly northern Spain), as well as those in central France and Belgium. Scandinavian regions which achieved outstanding improvements in productivity are regions with relatively low capital productivity rates and high labor productivity levels. In these regions, the growth in TFP was mainly due to improvements in technical efficiency. Productivity growth in southern European regions was primarily caused by technological progress. It can therefore be said that Scandinavian regions have succeeded in optimizing the use of their resources to a greater extent, while regions with generally high productivity rates were the most successful in absorbing technological progress.

Only 6 regions recorded negative average TFP growth rates in 2004-2015. The group of regions with the lowest productivity growth rates included Polish and Greek regions, as well as regions located in central Spain, Italy and several French regions. In some EU-15 regions, the fact that TFP does not grow rapidly is not a major problem because productivity levels are already relatively high. On the other hand, low or even negative growth in productivity, e.g. in Polish regions, may hinder the sustainable development of local farms. The results obtained are consistent with the conclusions of Cechura et al. (2014) who did not observe any catching-up in productivity among Member States when analyzing productivity levels in European agriculture. The average annual productivity improvement across the study group was ca. $2 \%$. This is similar to what was obtained by other researchers, including Fuglie (Dudu and Kristkova, 2017) who estimated the TFP growth rate in European agriculture to be ca. 1.6\%, with the highest values being recorded in Southern European countries and the Baltic states, while a slower pace of productivity improvement was observed in the east and west of the continent. In their study on productivity changes in EU countries between 2004 and
2013, Baráth and Fertő (2017) came to slightly different conclusions, pointing to a slight decrease in productivity. However, they noted the differences between new and old Member States. They also indicated that the process of productivity convergence between Member States takes place, albeit at a slow pace. Similar results are provided by Staniszewski (2018) who used the Malmquist index in his study on economic and environmental productivity in EU countries. He claimed that productivity increases faster in new Member States while some old Member States even experience a decline in TFP. On the other hand, Floriańczyk and Rembisz (2012) suggest that the 2002-2010 period witnessed a general decline in TFP across EU countries; values of TFP below 1 could be observed especially in new Member States, except for Poland and Slovakia. However, note that discrepancies in some results may be partially explained by the fact that this study is limited to FADN farms whereas some other studies address the agricultural sector as a whole. Furthermore, in each case, the researchers used different approaches for slightly different materials and time scopes, so the results are not directly comparable.

Productivity changes, in theory, should be directly linked to income changes. First of all, a high level of labor productivity should translate into a high level of labor profitability. It is therefore not surprising that the highest level of value added per unit of work was recorded in clusters $\mathrm{A}$ and $\mathrm{B}$, whereas in clusters $\mathrm{C}$ and $\mathrm{D}$ the values were about half that value (cf. Table 5). Relative differences in income between clusters are slightly smaller than in productivity, which may result from a lower level of agricultural costs in clusters C and D. Net income in each cluster is obviously lower than value added. Particularly significant differences are observed in clusters B and D, mostly composed of large farms using external means of production which cause an increase in their operating costs. In the whole study group, the average family farm income per unit of family work was EUR 19.9 thousand per year. In most clusters (A, B and D), it varied between the net value added per AWU and net income per AWU; but in cluster C, it was even slightly above the value added per AWU. Note also that data on family farm income is published only for family farms. It turns out that family farms in cluster C achieve particularly good economic results compared to farms with another ownership structure. As far as income per unit of land is concerned, the conclusions are 
Table 5. Mean values and average growth rates of income in delimited clusters in 2004-2015

\begin{tabular}{lccccccccc}
\hline \multirow{2}{*}{ Income variable } & Total & \multicolumn{3}{c}{ Mean (EUR thousand) } & \multicolumn{4}{c}{ Average growth rate (\%) } \\
\cline { 3 - 10 } & & $\mathrm{A}$ & $\mathrm{B}$ & $\mathrm{C}$ & $\mathrm{D}$ & $\mathrm{A}$ & $\mathrm{B}$ & $\mathrm{C}$ & $\mathrm{D}$ \\
\hline FNVA/AWU & 22.8 & 30.1 & 33.0 & 16.8 & 15.4 & 1.41 & 0.37 & 1.05 & 1.34 \\
NI/AWU & 14.0 & 21.8 & 17.1 & 13.6 & 10.0 & 1.85 & -0.28 & 0.60 & 0.71 \\
FFI/FWU & 19.9 & 28.6 & 27.0 & 17.1 & 13.6 & 2.02 & 0.63 & 1.34 & 1.21 \\
FNVA/ha & 1.0 & 3.56 & 0.63 & 1.30 & 0.57 & -1.29 & -0.66 & -1.38 & -0.30 \\
ROE (\%) & 9.2 & 7.8 & 9.4 & 9.1 & 9.7 & -2.83 & -2.35 & -0.37 & -1.30 \\
NI/total costs (\%) & 41.9 & 64.1 & 19.2 & 75.2 & 31.6 & 0.07 & -2.70 & -1.59 & -1.82 \\
NI-opp. costs/FWU & 1.6 & 7.7 & 4.3 & 0.8 & -0.8 & & & & \\
\% of cases with negative & 48 & 24 & 44 & 47 & 56 & & & & \\
income* & & & & & & & & & \\
\hline
\end{tabular}

FNVA: Farm Net Value Added; NI: Net Income; FFI: Family Farm Income; ROE: Net Income/Net Worth; opp. cost: costs of own labor, land and capital; *applicable to Net Income - opportunity costs

Source: own calculations based on the FADN database.

similar to those formulated for productivity. The highest values of this ratio are recorded in clusters A (high level of intensification) and $\mathrm{C}$ (climatic conditions conducive to specific lines of production). A much lower level of income (less than EUR 700 per hectare per year) was recorded in clusters B and D. The difference between the two clusters is only EUR 60 per hectare per year, although capital expenditure per hectare in cluster B was ca. $27 \%$ higher. The average return on equity in FADN holdings varied in the range of $9 \%$ to $10 \%$ in clusters $\mathrm{B}, \mathrm{C}$ and $\mathrm{D}$ during the period under examination, but the differences were not significant. Lower profitability levels $(7.8 \%$ on average) were recorded in cluster A farms which achieved high incomes, though at very high capital inputs. In the case of agricultural holdings, the ratio of income achieved to costs incurred could be a more adequate measure. Net income in relation to total costs was on average $64.1 \%$ in cluster $A$ and $75.2 \%$ in cluster $\mathrm{C}$, which should be viewed as very high rates of return, even if compared to other industries in the national economy. In clusters $\mathrm{B}$ and $\mathrm{D}$, the rates of return were much lower $(19.2 \%$ and $31.6 \%)$. If the farmers' own productive inputs are subtracted from net income, the income from agricultural holdings would be negative in more than half of observations (634 out of $1332 ; 12$ years multiplied by 111 regions). In clusters $\mathrm{A}$ and $\mathrm{C}$, the respective rates were $24 \%$ and $47 \%$, and in clusters B and D: $44 \%$ and $46 \%$. In conclusion, the best income situation was recorded in farms of cluster A. In cluster B, income per labor unit was slightly lower, but at a significantly lower level of profitability. In turn, in cluster $\mathrm{C}$, returns on both costs and equity were relatively high; however, the key income category (income per employee) was relatively low. As for the growth in labor income, the highest level was recorded in cluster A (in all categories), even though it demonstrated a high level of income from work and the slowest growth of both labor productivity and TFP.

Labor productivity in clusters $\mathrm{B}$ and $\mathrm{D}$ increased at a rate of ca. $3.5 \%$ p.a. (cf. Table 2), while the average annual increase in net income from agricultural holdings per employee was $0.71 \%$ in cluster D and was negative in cluster B. This means that in cluster B, efforts to improve productivity no longer resulted in adequate income growth. While growth was observed in cluster D (with low levels of income), an acceleration of the convergence process would require an increase in these dynamics. In the new EU regions, the increase in nominal agricultural income was partly consumed by a relatively high inflation rate. An alarming phenomenon may in turn be the declining profitability of land, equity and expenses. On the one hand, this is consistent with known theoretical laws. However, on the other hand, it may hinder the development of these farms in the long 
run. A relatively high increase in TFP productivity can be observed (cf. Table 4), but it translates into a low or negative income growth rate (cf. Czyżewski, 2017). The increase in agricultural incomes in certain new EU countries is also indicated by the results of other studies (cf. Szuba and Poczta, 2013). However, a separate problem which has not been analyzed in this paper is income instability. It mostly affects countries (regions) with lower incomes, and is partly due to their higher growth dynamics (Hill and Bradley, 2015).

\section{CONCLUDING REMARIS}

According to the European Union's policy, agriculture should achieve economic, social and environmental objectives. Although these goals apply to all regions, in practice they are achieved in different ways and to different degrees. This is a result of both the development level of the agricultural sector and the different conditions in which agriculture operates. In regions where agriculture is extremely intensive, high levels of (both partial and total) productivity were achieved. While there is little potential for productivity growth in these areas (especially through improved technical efficiency), local farms implement technological progress and have a high level of incomes.

In regions dominated by the industrial model of farming (e.g. Scandinavia), high (and further increasing) labor productivity ratios were recorded. On the other hand, the income-to-cost ratio and capital productivity were low; this suggests that the overall level of farming productivity in these regions was quite low. Thanks to improvements in technical efficiency of production after 2004, relatively high growth rates of total productivity and labor productivity were observed. However, it did not translate into high growth rates of income. This may suggest that agricultural industrialization is no longer an efficient path towards income growth.

Due to favorable climatic conditions and production patterns, farms in the Mediterranean regions achieved relatively high levels and growth rates of total productivity and high income-to-cost ratios. Moreover, capital and land productivity was high as well. On the other hand, because of high amounts of labor in relation to other productive inputs, labor profitability was relatively low and followed an average growth trend.

In regions where less developed or more traditional agriculture predominates (e.g Polish regions), low to medium levels of partial and total productivity were observed in most cases. On the other hand, farms in these regions still achieved relatively high ROE levels and relatively high growth rates of labor and land productivity. Also, the key economic category for the farming sector, i.e. income from labor inputs, was observed to grow at a relatively high pace.

The analyses conducted in this paper also indicate that the problem of agricultural productivity and profitability should be viewed through the prism of various measures and research methods. Focusing on only one indicator can lead to hasty conclusions and does not sufficiently reflect the complexity of on-farm processes in different EU regions.

\section{SOURCE OF FINANCING}

This publication is part of a project funded by the National Science Center (Poland) pursuant to decision No. UMO-2016/23/N/HS4/03453.

\section{REFERENCES}

Alston, J. M., Pardey, P. G. (2014). Agriculture in the global economy. J. Econ. Persp., 28(1), 121-146.

Arzeni,A., Esposti, R., Sotte, F. (2001). Agriculture in transition countries and the European model of agriculture: entrepreneurship and multifunctionality. The World Bank, ŠibenikKnin and Zadar Counties: Framework for a Regional Development Vision, University of Ancona. Retrieved from: https://www.researchgate.net/profile/Roberto Esposti/ publication/215665882_Agriculture_in_transition_coun tries_and the European_model_of_agriculture entrepre neurship_and_multifunctionality/links/02e 7 e 51 cbde 6 ad247f000000.pdf

Baráth, L., Fertő, I. (2017). Productivity and convergence in European agriculture. J. Agric. Econ., 68(1), 228-248.

Cardwell, M. (2004). The European model of agriculture. Oxford University Press on Demand.

Czyżewski, A. (2007). Uniwersalia polityki rolnej w gospodarce rynkowej. Ujęcie makro-i mikroekonomiczne [Universality of agricultural policy in market economy. Macro and microeconomic approaches]. Poznań: Wyd. AE w Poznaniu [in Polish].

Czyżewski, B. (2017). Kierat rynkowy w europejskim rolnictwie [Market treadmill in European Agriculture]. Warszawa: Wyd. Nauk. PWN [in Polish].

Ćwiąkała-Małys, A., Nowak, W. (2011). Dekompozycja indeksu produktywności Malmquista w modelu DEA 
[Decomposition of Malmquist productivity index in DEA model]. Przegl. Prawa Admin., 85, 273-284 [in Polish].

Čechura, L., Grau, A., Hockmann, H., Kroupová, Z., Levkovych, I. (2014). Total Factor Productivity in European Agricultural Production. COMPETE Working Paper, No 9.

Dańska-Borsiak, B. (2011). Dynamiczne modele panelowe $\mathrm{w}$ badaniach ekonomicznych [Dynamic panel models in economic studies]. Łódź: Wyd. Uniwersytetu Łódzkiego [in Polish].

Dudu, H., \& Smeets Kristkova, Z. (2017). Impact of CAP Pillar II payments on agricultural productivity. JRC Technical Reports. Luxembourg: Publications Office of the European Union. [https://core.ac.uk/download/pdf/84886878. pdf]

Fare, R., Grosskopf, S., Norris, M., \& Zhang, Z. (1994). Productivity growth, technical progress, and efficiency change in industrialized countries. American economic review, 84(1), 66-83.

Floriańczyk, Z., Rembisz, W. (2012). Dochodowość a produktywność rolnictwa polskiego na tle rolnictwa unijnego w latach 2002-2010 [Profitability and productivity of Polish agriculture versus those of EU agriculture in 2002 2010]. Zesz. Nauk. SGGW Warsz. Probl. Roln. Świat., 12(1), 53-62 [in Polish].

Frija, A., Dhehibi, B., Aw-Hassan, A., Akroush S., Ibrahim A. (2015). Approaches to Total Factor Productivity Measurements in the Agriculture Economy. CGIAR Research Program on Dryland Systems. Retrieved from: http://repo. mel.cgiar.org/handle/20.500.11766/4389.

Gloy, B. A., Hyde, J., LaDue, E. L. (2002). Dairy farm management and long-term farm financial performance. Agric. Res. Econ. Rev., 31(2), 233-247.

Goddard, E., Weersink, A., Chen, K., Turvey, C. G. (1993). Economics of structural change in agriculture. Canad. J. Agric. Econ., 41(4), 475-489.

Hayami, Y., Ruttan, V. W. (1970). Factor prices and technical change in agricultural development: The United States and Japan, 1880-1960. J. Polit. Econ., 78(5), 1115-1141.

Herlemann, H. H., Stamer, H. (1963). Rolnictwo w dobie technizacji [Agriculture in the age of technicalisation] Warszawa: PWRiL [in Polish].

Hill, B., Bradley, B. D. (2015). Comparison of farmers' incomes in the EU member states. Report for European Parliament, European Commision, DG Internal Policies.

Idczak, J. (2001). Dochody rolnicze a polityka rozwoju regionalnego Unii Europejskiej [Agricultural incomes and regional development policy]. Poznań: Wyd. WSB [in Polish].
Jepsen, M. R., Kuemmerle, T., Müller, D., Erb, K., Verburg, P. H., Haberl, ..., H., Björn, I. (2015). Transitions in European land-management regimes between 1800 and 2010 . Land Use Policy, 49, 53-64.

Kleinhanss, W. (2015). Konkurencyjność głównych typów gospodarstw rolniczych w Niemczech [Competitiveness of the major types of agricultural holdings in Germany]. Zagad. Ekon. Roln., 342(1), 25-41 [in Polish].

Kryszak, Ł. (2018). Profit efficiency in EU FADN farms under different types of agriculture. Probl. World Agric., 18(3), 196-207.

Martín-Retortillo, M., Pinilla, V. (2015). On the causes of economic growth in Europe: why did agricultural labour productivity not converge between 1950 and 2005? Cliometrica, 9(3), 359-396. Retrieved from: http://www.ehs.org. uk/dotAsset/b8cd30e1-e0d3-4f6d-981b-9b1af36b7a33. pdf

Rembisz, W. (2010). Mikroekonomiczne zależności między wskaźnikami produktywności i cen a dochodami w rolnictwie. Ujęcie analityczne [Microeconomics of the Productivity, Price Indicators and Farm Incomes. Analytical Approach]. Współcz. Ekon., 4(2), 5-20 [in Polish]. Retrieved from: http://yadda.icm.edu.pl/yadda/element/bwmeta1. element.ekon-element-000171296317;jsessionid=7EBD7 6397A433361D8ACA6E1B55A4032.

Rembisz, W. (2013). Kwestie ryzyka, cen, rynku, interwencji i stabilności dochodów w rolnictwie [Risk, price, market, intervention and income stability issues in agriculture]. Warszawa: Vizja Press \& IT [in Polish].

Sraffa, P. (1960). Production of Commodities: Prelude to a Critique of Economic Theory. Cambridge University Press.

Staniszewski, J. (2018). Attempting to measure sustainable intensification of agriculture in countries of the European Union. J. Environ. Prot. Ecol, 19, 949-957.

Szuba, E., Poczta, W. (2013). Próba oceny wpływu wspólnej polityki rolnej na zmiany sytuacji ekonomicznej w rolnictwie krajów środkowo-wschodniej Europy [Attempt to assess the impact of the CAP on the change of the economic situation in the agriculture in Central-Eastern European countries]. Rocz. Nauk. SERiA, 5(15), 293-299 [in Polish].

Zegar, J. S. (2012). Współczesne wyzwania rolnictwa [Contemporary issues in agriculture]. Warszawa: Wyd. Nauk. PWN [in Polish]. 